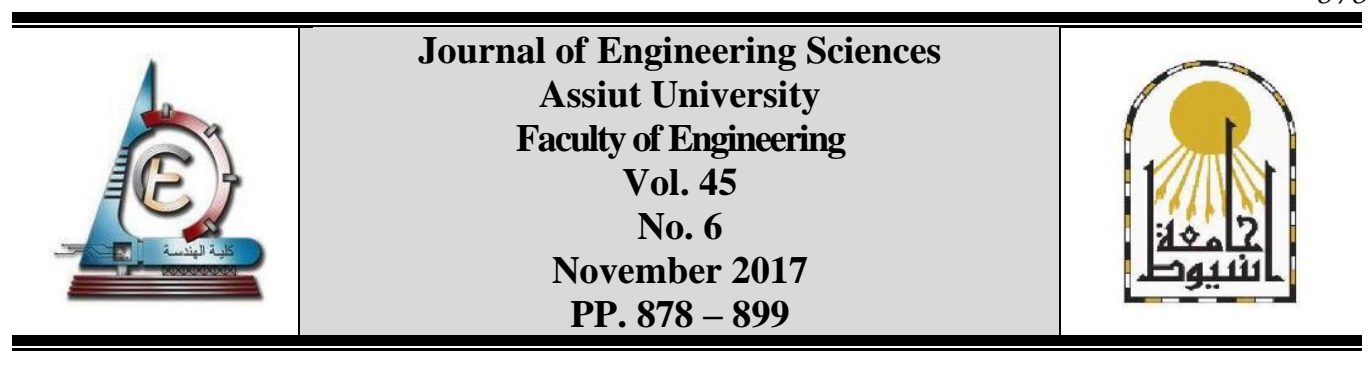

\title{
PERFORMANCE IMPROVEMENT FOR PUBLIC CONSTRUCTION PROJECTS USING RISK ANALYSIS
}

\author{
Mohamed Said Meselhy Elsaeed \\ Architecture Department, Faculty of Engineering, Fayoum University, Fayoum, Egypt \\ Email address:dr.meselhy@waveegypt.com
}

Received 7 November 2017; Accepted 12 December 2017

\begin{abstract}
In the last five years, many of the construction projects faced a lot of new variables which stopped or delayed in the commission some of these projects, Most of them its cost had been raised up or implemented with low quality and low performance not as it was planned. The new variables which faced the construction projects came as result of new changes on the international level which effected directly on our local level, The political term made new regulation and policies effected on the construction industry, Social term created negative behavior between the partnerships in the construction industry, Economic term made unexpected results on the construction projects and the investment projects on general that because the increasing in the building materials cost and the labor cost rates which led to raise up the total budget of this projects not as it was planned.

The research aims to achieve the risk analysis job plan which is leading improve the performance of public construction projects with that new variable in the last five years through presenting a risk analysis job plan (risk planning, risk identification, qualitative analysis, quantitative analysis, risk treatment and risk monitoring and control) of a public construction project on the local level as a case study. The research will present the effect of the risk analysis on the public construction project's performance to be able to face the uncertainties events through the implementation stage.
\end{abstract}

Keywords: Risk, New Variables, Probability, Impact, qualitative, quantitative

\section{Introduction}

Construction industry differs from other industries which could be managed through control and monitoring for production process. The construction industry can't be repeated as other industries, each project is considered a special condition than other according to the type of buildings, types of businesses, target schedule, expected budget in addition to political conditions, private or public oriented project, and location circumstances. Construction projects face a lot of different issues that lead to the delays and increase of budget much more than were planned during the early stages of projects. The construction projects are characterized by diversity of stakeholders affecting the project; starting form client that could include project owner, investors, and funding, insurance companies; in addition to group specialized consultants in different disciplines, main contractor, subcontractors and a lot of suppliers. 
The construction projects face problems time, cost, and quality. Concerning time aspect, the problems may be due to Political conflict may cause disturbance in workflow, in addition to poor communication between construction parties during design or constructing process that will lead to lack of project organization. While for Cost problems it may be caused by economic instability that will raise the delay in payment for construction parties, dispute between parties and financial problems of the owner or contractor. As for Quality problems, it may be generated from failure to keep the contracts consistent between parties, or failure to document project changes or expectations properly, inability of project parties to follow building codes or regulations or standards. [8]

Generally, the problems mentioned above that can't be defined or identify as the only problems for construction industry. There are a lot of uncertainties events that can negatively impress project's time, cost or quality. The paper will use risk analysis process to achieve main aim that to improve performance of public construction projects using risk identification and risk response.

\subsection{Research problem}

Many of the investment and public construction project faces unexpected new variables as a result of the international changes which effected on the local level in last five years, this unexpected new variable created negative impacts on the public construction projects in one aspect or more at the management triangle (Time- cost- quality).Based on the financial stability report of the Arabic Republic of Egypt (2014) prepared by the central bank of Egypt, the revaluations economical follows had big effect on the third quarter of $2010 / 2011$ as the growth rate fell to $(-3.8 \%)$ instead of $(5.6 \%$ )on the third quarter of $2009 / 2010$ that's was a result that many of the economic sectors were affected one of this sectors was the construction and building sector.[15]

There is a need to develop the performance of public projects and prepare the projects to avoid uncertainty events that could happen based on a current circumstances and prediction of problems in future.

\subsection{Research aim}

The research aims to achieve the risk analysis job plan which is lead to improve the public construction projects performance by using risk methodology and activate the risk management in the early phases at this project to be able to face the uncertainties events. In order to achieve the main aim, the research will apply secondary aims; definition of risk management methodology, steps of risk management plan, identification of most probable risk list for construction projects \& its treatment plan. 
Mohamed Said Meselhy Elsaeed, Performance improvement for public construction projects ....

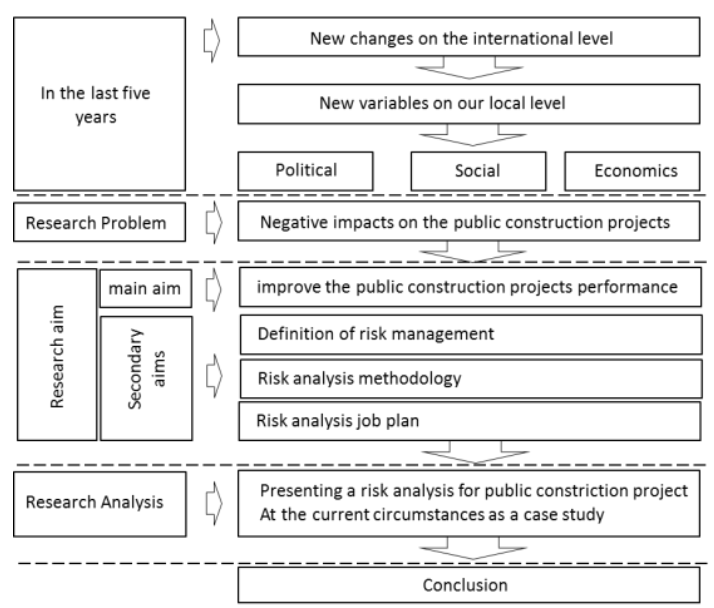

Fig. 1. Research methodology - Source: By Auther

\section{Risk management definitions}

Risk management is considered a crucial process to the success of construction projects. Contractors who are working in the Egyptian construction industry need a simple \& effective tool to help them properly identify the risks that they may face and the associated response methods to these risks. Thus, they can firmly deal with risks and can better assess their impact on construction projects by using risk analysis instead of taking in consideration the common 5\% risk contingency assumed by contractors in their bids. [1]

Management of construction project risks in the developing countries is an unavoidable issue for different parties. Despite that fact that Egypt has taken board steps towards building a strong economy, the Egyptian economy is still struggling to overcome many barriers, e.g. the high inflation rate; the fluctuating exchange rate; and the foreign convertibility. Meanwhile, Egypt is enjoying unstable political environment, the contractors working in the Egyptian construction industry frequently complain of problems such as the frequently updated laws and regulations concerning the construction industry and corruption that is inherent in any business. [5]

According to Oxford advanced Learner's dictionary, risk is defined as the possibility of meeting danger or of suffering harm or loss.

HAROLD KERZNER defines risk as a "measure of the probability and consequence of not achieving a defined project goal. He stated that risk has three primary components; an event which is an unwanted change; in addition to probability of occurrence of that event; \& Impact of that event (amount at stake)". [4]

DAVID HILLSON presented a debate between two opinions. The first opinion considers risk as an umbrella term with two varieties, opportunity that is a risk with positive effects and threat that is a risk with negative effects. On the contrary, the second opinion considers uncertainty as the overarching term with two varieties, risk referring exclusively to threat, i.e. an uncertainty with negative effects and opportunity that is an uncertainty with positive effects. [3]

The most recent definition for Risk management is " the identification, assessment, and prioritization of risks (defined in ISO 31000 as the effect of uncertainty on objectives) followed by coordinated and economical application of resources to minimize, monitor, 
and control the probability or impact of unfortunate events[13] or to maximize the realization of opportunities. Risk management's objective is to assure uncertainty does not deflect the endeavor from the business goals." [14]

On the other hand, the tender price for different items or activity can be divided into two main aspects as shown in fig 1; cost which could be direct or indirect cost; and markup which consists of contingency (analysis of risk) and profit acquired. [5]

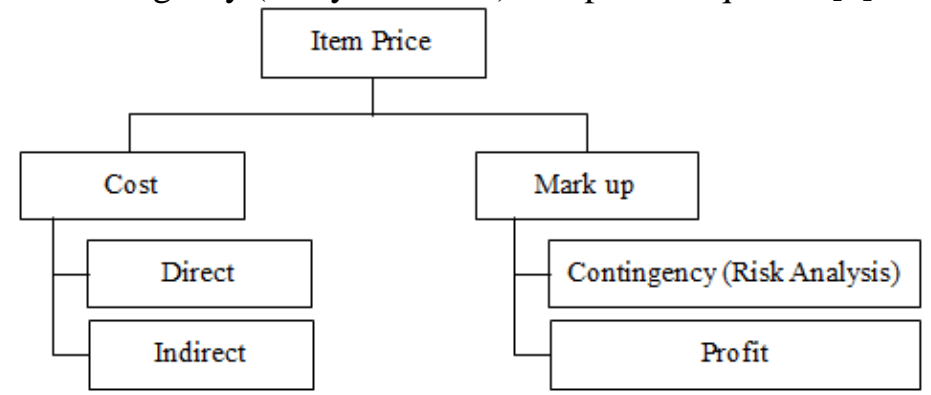

Fig. 2. Tender Item price Source:The Professional program in Project Management(PRMG),Project Risk Management(PRMG095), American University in Cairo, Dr. A.Samer Ezeldin, Lectures, 2009

\section{Timeliness risk management}

Risks arise because of uncertainty about the future. Risk display may arise from the possibility of economics, financial or social loss or gain, physical damage or injury, or delay. It may also be caused by changes in relationships between the partner involved in the supply, ownership, operation and maintenance of assists for public or privet purpose. Risk management provides a job plan as a structured way of assessing with future uncertainty. The project risk management process applies across all project stages. There are many different requirements for risk analysis and management at the different phases in the life of project proposal .For big projects, several risk analysis may be conducted .Risk management process are designed to assist planners and manager in identifying significant risk and developing measure to address them and their consequences. This leads to more effective and efficient in their decisions, more of certainty about outcomes and reduced risk appear. [11]

In the later phase of a project, the main goal is on effective and efficient delivery .Risk analysis is directed towards ensuring more reliable outcomes are achieved in terms of timeliness, cost and quality of the construction projects and the services that are provided.

Many originations often involve unbalanced cash flow, requiring large initial investment before returns are obtained. In case these circumstance, there may be significant uncertainty about the future cash flow, due to changing in the economic conditions, advances in technology, changing patterns or forms of demand for building raw materials or services, new completion in the market. For projects with significant social or environmental modulation, the benefit may not be readily measurable in cash terms and social values may face new changes during the life. These Factors must be assessed and managed to ensure the capital or large investment is worthwhile. [10]

\section{Risk management job plan [6], [7]}

Most researchers, to a great extent, agreed about the steps of a proper risk management process. However, there were some differences in how researchers organize or called these 
Mohamed Said Meselhy Elsaeed, Performance improvement for public construction projects ....

steps; Risk Management Planning; Risk Identification; Qualitative Analysis; Quantitative Analysis ; Response Planning ; \& Monitoring \& Control.

\subsection{Risk management planning}

Risk management planning defines the development structure for risk identification and analysis that will be utilized in the following stages. It needs to identify organizational and project documentation, stakeholder analysis, criteria success and set of key elements. It aims to generate likelihood (probability) and impact grading system, severity grading system and risk treatment grading system.

\subsection{Risk identification}

Risk identification defines the events that might affect the project goals, and it shows how these events might happen. This stage might needs information based on historical data, theoretical analysis, in addition to empirical data and analysis. It aims to generate a comprehensive list of possible risks that might face the project in the future. The risk identification could be generated through different types; brainstorming, checklists, questionnaires, similar projects and specialist techniques. [2]

\subsection{Qualitative analysis}

Risk qualitative analysis defines the overall process of risk analysis and assessment. It aims to generate priorities for different identified risks. It aims to determine how often specified events may occur and the magnitude of their consequences. It may also include historical data, theoretical analysis, in addition to empirical data and analysis, informed opinions of experts and stakeholders. The qualitative analysis will generate a list of prioritized risks and their impact on the project, and likelihood ratings and consequences.

\subsection{Quantitative analysis}

Risk quantitative analysis defines quantitative values for risk impacts and likelihood generated by last stage using grading system mentioned in risk management planning . The qualitative analysis will generate a graded list of prioritized risks and their impact on the project, and likelihood ratings and consequences. . It aims to generate severity factor of risks by multiplication of likelihood (probability) factor and risk impact factor. The risk severity factor will be influence the project cost by certain value generated by grading system mentioned in risk management planning. [9]

\subsection{Risk treatment}

Risk treatment defines the methodology to decrease the impact of risk identified in early stages. Risk treatment has three main types; adding cost to project as a contingency, risk response in contract agreement, adding risk to watch list to take in consideration during construction without certain response.

\subsection{Risk Monitoring and control}

Risk monitoring and control defines the strategy to review the risk and assure the implementation of risk treatment through risk register, in addition to observe project to avoid occurrence of new risks. 


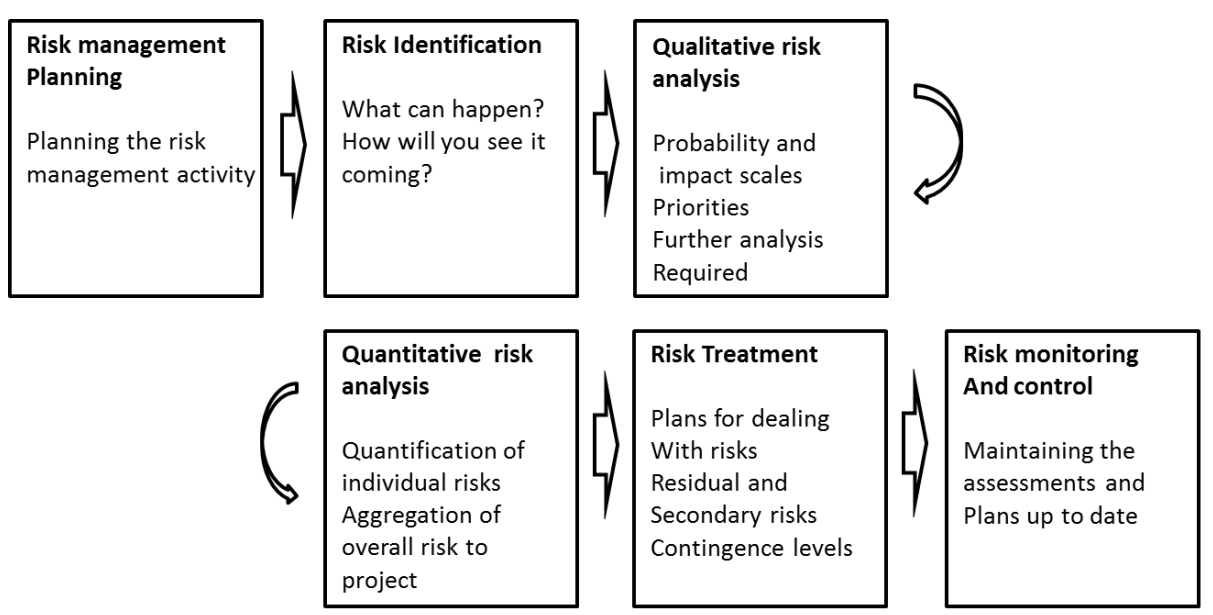

Fig. 3. The PMBOK project risk management process - Source: Cooper D., Grey S., Raymond G., Project Risk Management guidelines, managing risk in large projects and complex procurement, 2005.

\section{Administration building case study}

The case study for the research will study administration building in the new Cairo; the owner is one of the real estate companies. The building consists of ground floor, basement floor and three typical floors. Its start the implementation phase at 2015 with total budget equals 11 million and 400 thousand. The research will study risk for the administration building according to above mentioned steps for risk analysis.

\subsection{Risk management planning}

The Stakeholders for the administration building was identified as follows;

- The Owner.

- The Engineer.

- The Contractor.

- Residents

- Clients.

- Armed forces departments
- General organization for bridges \& highways

- General administration for transit.

- Civilian defense departments

- Ministry Civil aviation

- Ministry of electricity

By using the bill of quantities of the case study had been divided to 12 divisions based on the all types of the activities. On the other hand, All the activities which related to the concrete works like Rain forced concrete in the substructure (footing, shear walls, etc.) and the super structure (columns, beams, slabs, frames ,etc.) had been included in the Concrete division, and also all activities which related to the bricks work (brick walls thickness 25 $\mathrm{cm}$, brick walls thickness $12 \mathrm{~cm}$, ..etc) had been included in the masonry division, with this concept the research created the main divisions as shown in table (1) 
Mohamed Said Meselhy Elsaeed, Performance improvement for public construction projects ....

\section{Table 1.}

Bill of quantity summary - Source: administration building documentation

\begin{tabular}{|c|l|c|}
\hline Item & \multicolumn{1}{|c|}{ Description } & Amount L E. \\
\hline 1 & Division 1 : EXCAVATION & 461,477 \\
\hline 2 & Division 2 : CONCRETE & $2,680,210$ \\
\hline 3 & Division $3:$ MASONARY & 720,072 \\
\hline 4 & Division $4:$ METALS & 235,517 \\
\hline 5 & Division $5:$ THERMAL AND MOISTURE PROTECTION & 759,821 \\
\hline 6 & Division 6 : DOOR \& WINDOWS & 292,058 \\
\hline 7 & Division $7:$ FINISHES & $3,416,006$ \\
\hline 8 & Division $8:$ PAINTING & 251,854 \\
\hline 9 & Division $9:$ SPECIALTIES & 407,200 \\
\hline 10 & Division 10: Fire Protection System & 262,800 \\
\hline 11 & Division 11: Mechanical & $1,642,500$ \\
\hline 12 & Division 12: Electrical & 306,600 \\
\hline & & $11,436,114$ \\
\hline
\end{tabular}

\section{Table 2.}

Probablity grading system - Source: Professional program in project management, American Univeristy in Cairo, 2012.

\begin{tabular}{|c|c|}
\hline \multicolumn{2}{|c|}{ Probability } \\
\hline Rates & Values \\
\hline V.H & 0.9 \\
\hline H & 0.7 \\
\hline M & 0.5 \\
\hline L & 0.3 \\
\hline V.L & 0.1 \\
\hline
\end{tabular}

This table is explaining and presenting the probability grading system which the research used it in the qualitative analysis. This grading system shows the relations between the rates and its values, the rates divided in to five items \{very high (V.H), high $(\mathrm{H})$, medium $(\mathrm{M})$, low (L), very low (V.L) \} come upon its values starting from 0.9 to 0.1 as shown in table (2). [12]

\section{Table 3.}

Impact grading system - Source: Professional program in project management, American Univeristy in Cairo, 2012

\begin{tabular}{|c|c|}
\hline \multicolumn{2}{|c|}{ Impact } \\
\hline Rates & Values \\
\hline V.H & 0.8 \\
\hline H & 0.4 \\
\hline M & 0.2 \\
\hline L & 0.1 \\
\hline V.L & 0.05 \\
\hline
\end{tabular}


This table is explaining and presenting the impact grading system which the research used it in the qualitative analysis. This grading system shows the relations between the rates and its values, the rates divided in to five items \{very high $(\mathrm{V} . \mathrm{H})$, high $(\mathrm{H})$, medium $(\mathrm{M})$, low $(\mathrm{L})$, very low (V.L)\} come upon its values starting from 0.8 to 0.05 as shown in table (3). [12].

\section{Table 4.}

Severity grading system - Source: Professional program in project management, American Univeristy in Cairo, 2012

\begin{tabular}{|c|c|c|}
\hline \multicolumn{2}{|c|}{ severity } & \multirow{2}{*}{ Additional Cost } \\
\hline Min & Max & \\
\hline $40 \%$ & $100 \%$ & $2.0 \%$ \\
\hline $25 \%$ & $40 \%$ & $1.5 \%$ \\
\hline $10 \%$ & $25 \%$ & $1.0 \%$ \\
\hline $5 \%$ & $10 \%$ & $0.75 \%$ \\
\hline $0 \%$ & $5 \%$ & $0.25 \%$ \\
\hline
\end{tabular}

We get the severity value by multiplying probability value with impact value. The table (4) is presenting for relations between the minimum and maximum severity values with additional cost which have been added to the actual cost, as an example if the severity value comes between $25 \%$ to $40 \%$ this mean that we need to add $1.5 \%$ to the actual cost, and this will be applied on all of the severity values. [12]

\section{Table 5.}

Severity alocations - Source: Professional program in project management, American Univeristy in Cairo, 2012

\begin{tabular}{|c|c|c|c|c|c|}
\hline Probability & \multicolumn{5}{|c|}{ Threats } \\
\hline 0.9 & 0.045 & 0.09 & 0.18 & 0.36 & 0.72 \\
\hline 0.7 & 0.035 & 0.07 & 0.14 & 0.28 & 0.56 \\
\hline 0.5 & 0.025 & 0.05 & 0.1 & 0.2 & 0.4 \\
\hline 0.3 & 0.015 & 0.03 & 0.06 & 0.12 & 0.24 \\
\hline 0.1 & 0.005 & 0.01 & 0.02 & 0.04 & 0.08 \\
\hline Impact & 0.05 & 0.1 & 0.2 & 0.4 & 0.8 \\
\hline
\end{tabular}

This table shows the different severity values which we got it by multiplying probability value with impact value, If the severity values comes in the green zone this means we need to add additional cost as mentioned before, If the severity values comes in the gray zone this means we need to make a risk response only, If the severity values comes in the yellow zone this means it's a watch list as shown in table (5) and (6). [12]

Table 6.

Risk Treatment Key map

\begin{tabular}{|c|c|}
\hline & Quantitative \\
\hline & Risk Response \\
\hline & Watch List \\
\hline
\end{tabular}


Mohamed Said Meselhy Elsaeed, Performance improvement for public construction projects ....

\subsection{Risk identification}

The risk identification could be generated through main two ways; checklists for similar projects and questionnaires with experts in this field. The risk identification was divided into four categories; technical, financial, legal \& environmental aspects [2] as shown in table (7)

Table 7.

Risk identification - Source: Author

\begin{tabular}{|c|c|c|}
\hline Risk Categories & No. & Type Of Risk \\
\hline \multirow{11}{*}{ Technical } & 1 & Damage in electrical resources \\
\hline & 2 & Rocks \\
\hline & 3 & Cut cables during work \\
\hline & 4 & Damage in mechanical equipment \\
\hline & 5 & Poor Design \\
\hline & 6 & Low Production Rate \\
\hline & 7 & Defective Delivery Material \\
\hline & 8 & Improper Project Management \\
\hline & 9 & an apology some Suppliers for delivery material \\
\hline & 10 & Error in the execution method \\
\hline & 11 & Transfer to unqualified sub- contractor \\
\hline \multirow{5}{*}{ Financial } & 12 & Custom Tariff \\
\hline & 13 & Dollar exchange rate \\
\hline & 14 & Delay in pay invoice amount \\
\hline & 15 & Error in cost estimate \\
\hline & 16 & change Traffic laws \\
\hline \multirow{2}{*}{ Legal } & 17 & Approvals \& Permits \\
\hline & 18 & Bad Weather \\
\hline \multirow{4}{*}{ Environmental } & 19 & Lack of workers do not complete the schedule \\
\hline & 20 & Error in time estimate \\
\hline & 21 & the resignation of specialized employment \\
\hline & 22 & Safety \\
\hline
\end{tabular}

\subsection{Qualitative analysis}

The qualitative analysis will generate a list of prioritize risks and their impact on the project, and likelihood ratings and consequences through questionnaire for 12 experts; who vary from project managers, project executives and project engineers with range of expertise from 15 to 20 years.

\subsection{Quantitative analysis}

The quantitative analysis used the probability grading system and impact grading system in table 2 and table 3 respectively and got the severities values for each as it explained before.

\subsection{Risk treatment}

Risk treatment will use severity factor for different risks generated during quantitative analysis. The type of risk treatment will be defined as result of risk treatment grading system table (5) by using the three main classification, the Quantitative (green color) for 
additional cost, Risk response (gray color) must be taken in our consideration at the agreements stage and the watch list (yellow color) must be controlled.

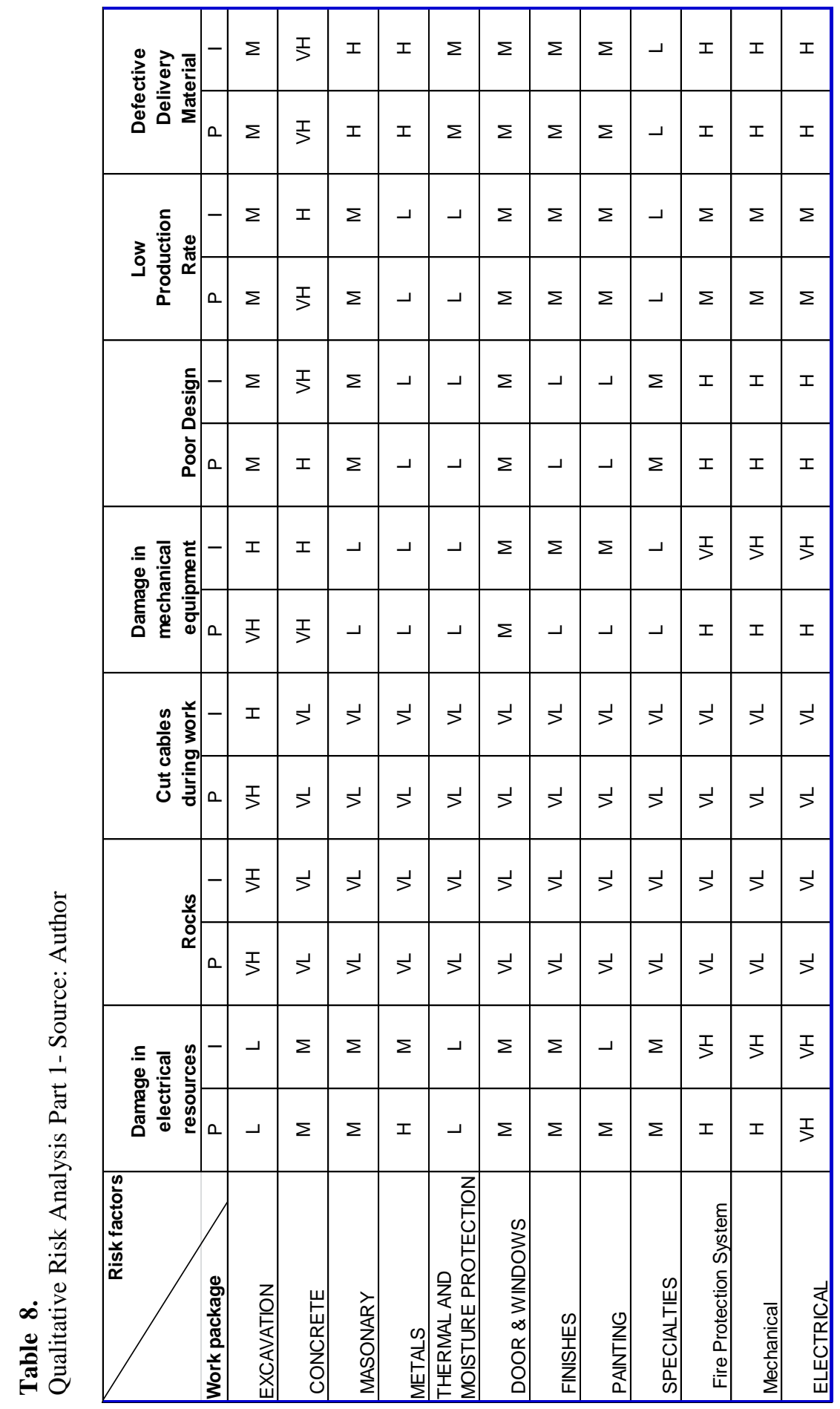




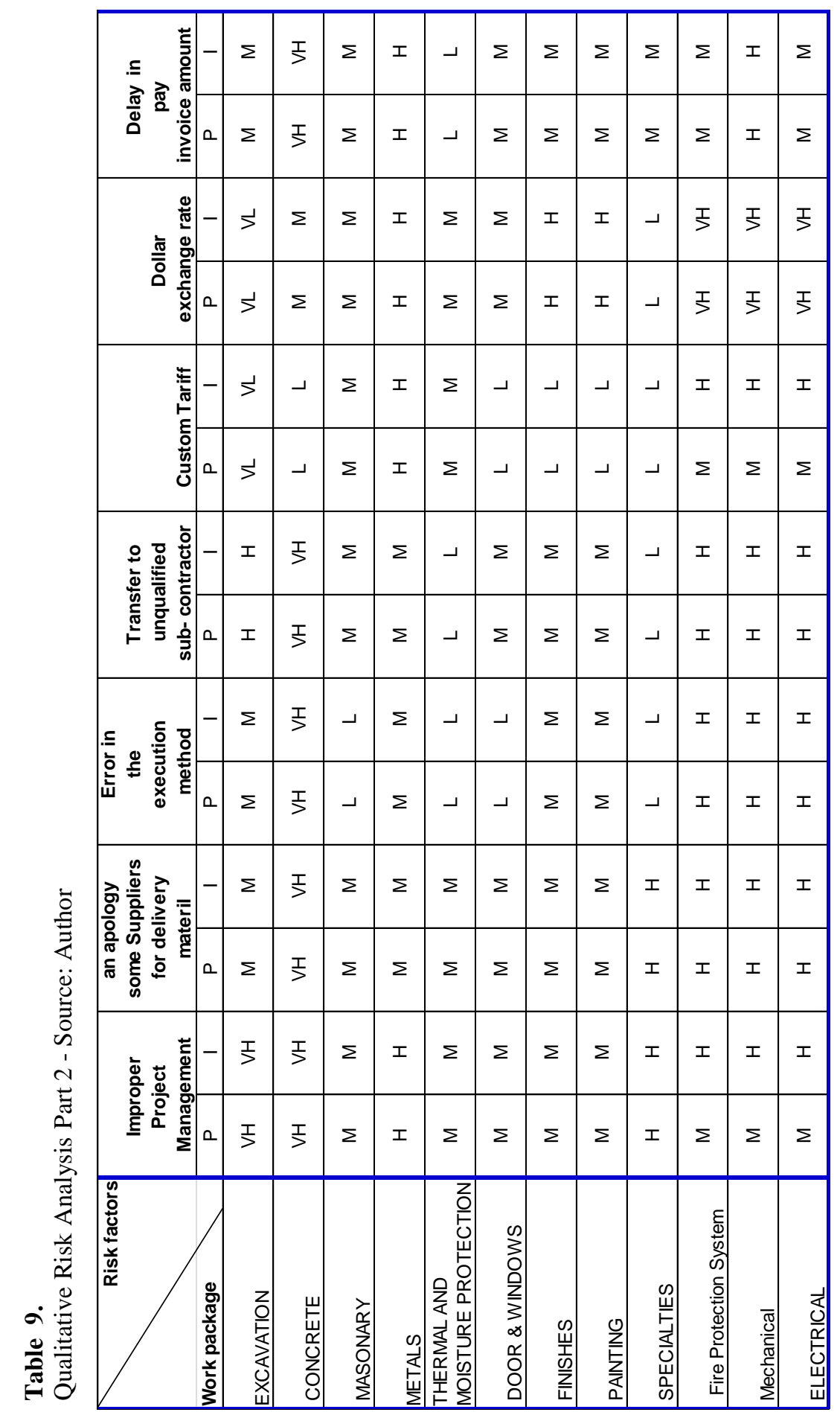




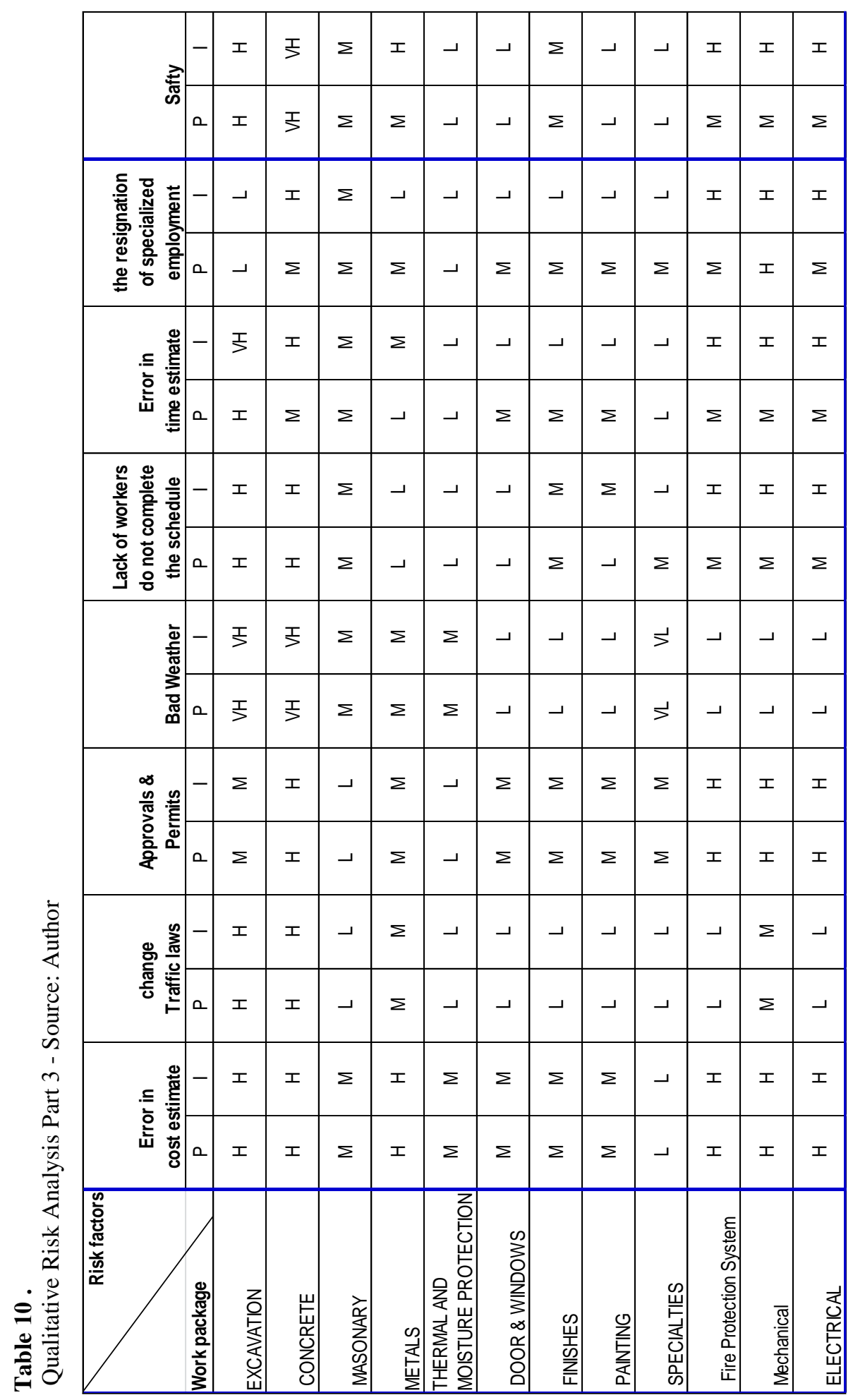




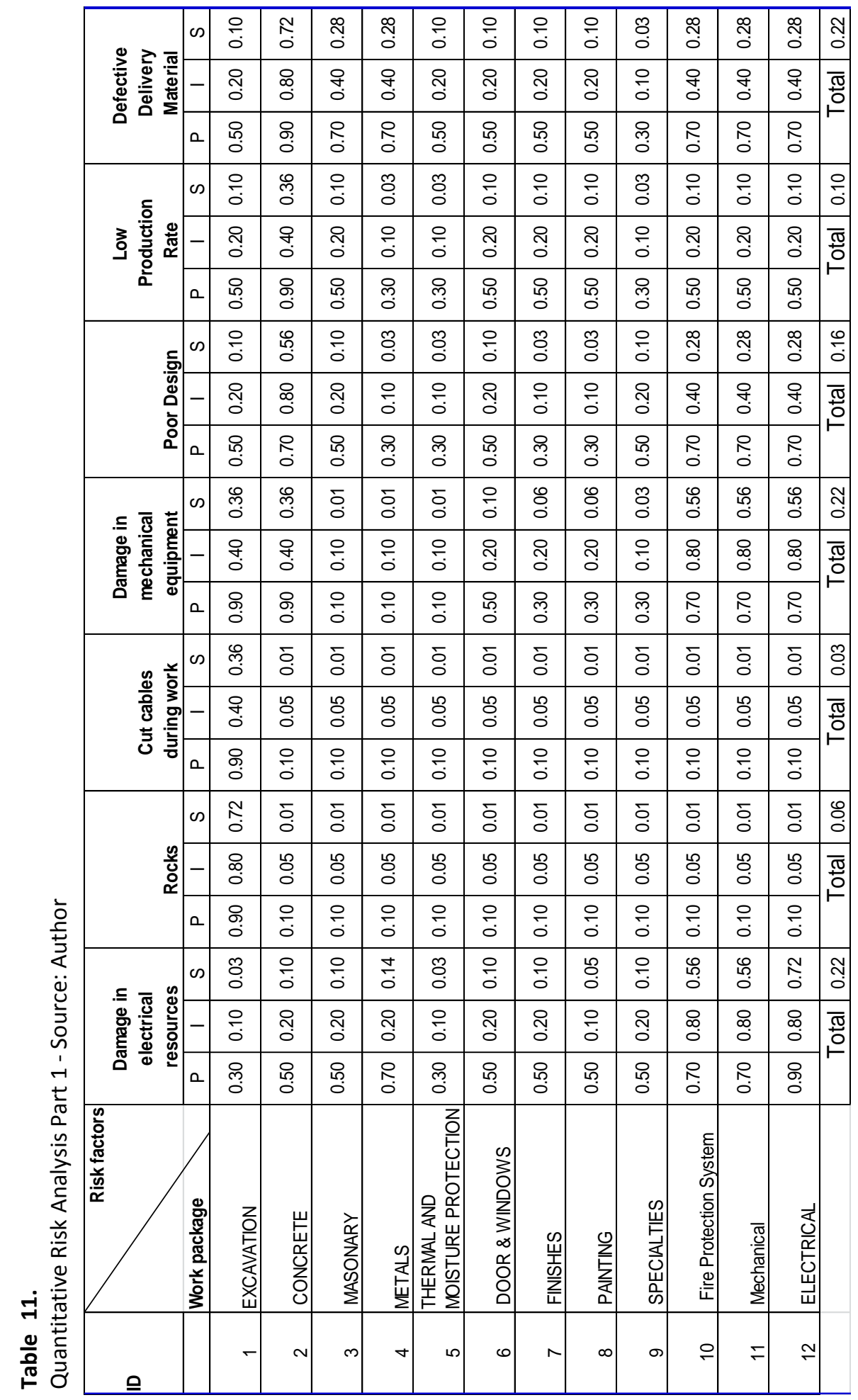




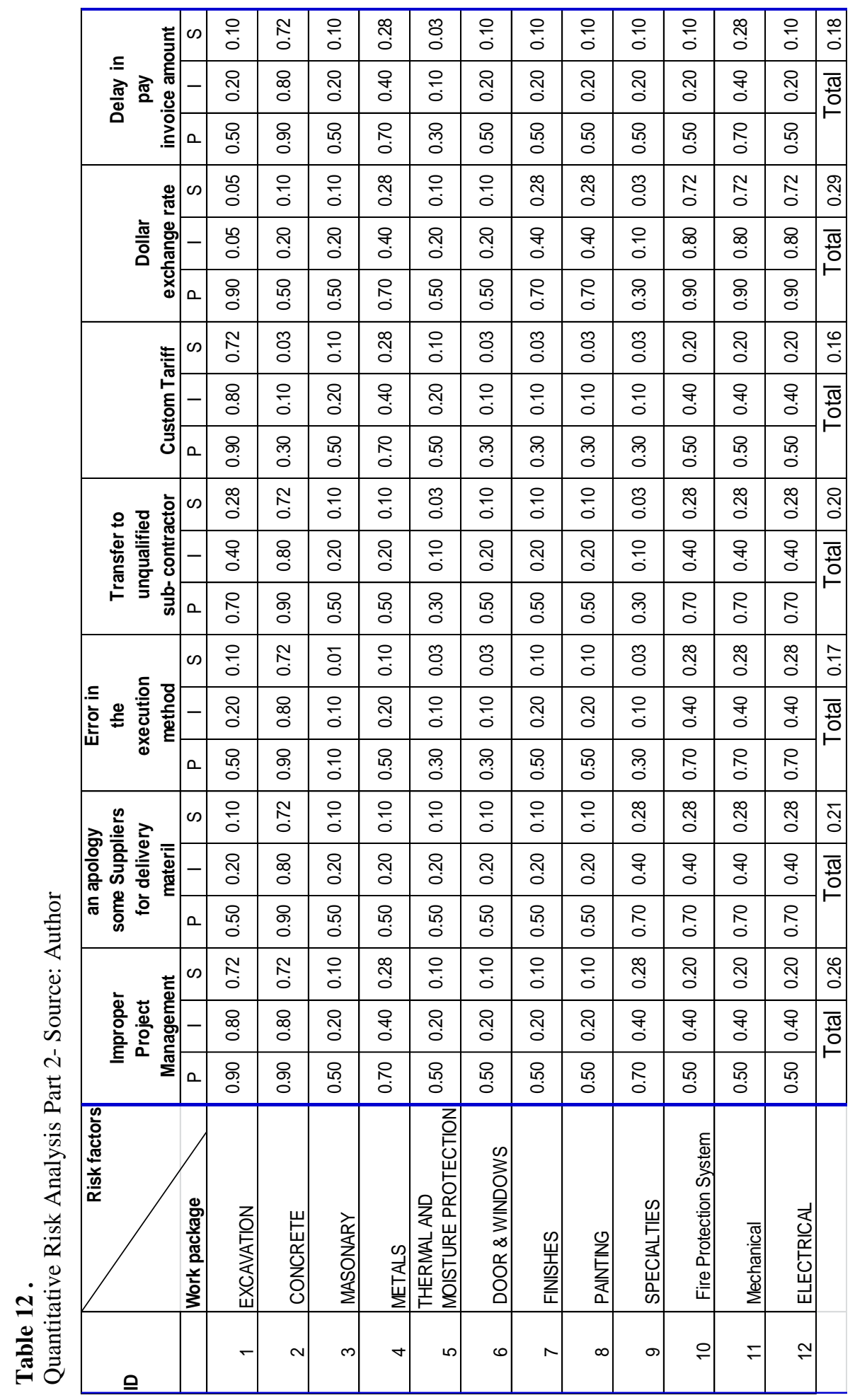




\begin{tabular}{|c|c|c|c|c|c|c|c|c|c|c|c|c|c|c|c|}
\hline & \multirow{3}{*}{ 蛋 } & $\infty$ & 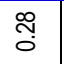 & $\underset{\mathfrak{O}}{\mathbb{N}}$ & 응 & న్ & ס̊. & ס̊: & 응 & ס̊ㅁㅇ & ס্ర0 & ণ్రి & ণ్రి & ণ్రి & $\begin{array}{l}0 \\
\\
\end{array}$ \\
\hline & & 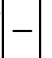 & g & $\begin{array}{l}\text { D. } \\
0\end{array}$ & ণ్రి & g & 응 & 응 & శ్రి & 응 & $\frac{}{0}$ & 웅 & go & gi & \multirow[t]{2}{*}{ 坖 } \\
\hline & & 0 & $\begin{array}{l}\text { R } \\
0\end{array}$ & 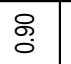 & 员 & 员 & প్య & ஓ్ & 员 & ஓ্ণ & ஓ్ & 员 & 苔 & 员 & \\
\hline & \multirow{3}{*}{ 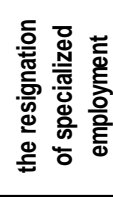 } & $\infty$ & סֶ: & ণัণ & 응 & $\stackrel{2}{\circ}$ & סु. & $\stackrel{2}{2}$ & $\stackrel{2}{\circ}$ & $\stackrel{2}{2}$ & $\stackrel{2}{2}$ & กิ & $\begin{array}{l}\stackrel{0}{0} \\
\stackrel{0}{0}\end{array}$ & ণัָ & E. \\
\hline & & - & 응 & 웅 & ণัญ & 응 & 응 & $\frac{0}{0}$ & 응 & 응 & 응 & 웅 & 导 & 昌 & \multirow[t]{2}{*}{ 퓽 } \\
\hline & & 0 & ల్రా & 员 & م. & 용 & প্ণ & 웅 & 융 & 웅 & 융 & 号 & R & 융 & \\
\hline & \multirow{3}{*}{ 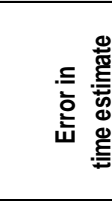 } & $\infty$ & : & ণ్రి & $\frac{}{0}$ & $\stackrel{8}{0}$ & ס̊ & $\stackrel{2}{0}$ & 능 & $\stackrel{2}{0}$ & ס̊ㅇㅇ & ণิ & ণิ & ণ్రి & $\begin{array}{l} \pm \\
\vdots \\
\end{array}$ \\
\hline & & - & @ & ơ & ণ్రి & న్ণి & 응 & 응 & 응 & 응 & 응 & o & g & g & \multirow[t]{2}{*}{ 퓽 } \\
\hline & & a & R & 员 & 융 & 品 & 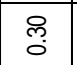 & 융 & 융 & 员 & 용 & 융 & 융 & 융 & \\
\hline & \multirow{3}{*}{ 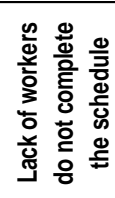 } & $\infty$ & 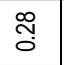 & న్ & 응 & סֶ: & סூ: & ס̊: & 응 & $\ddot{0}$ & 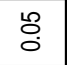 & న్రి & న్ & న్ & $\begin{array}{l}0 \\
0 \\
0\end{array}$ \\
\hline & & \begin{tabular}{|l|}
- \\
\end{tabular} & 웅 & 웅 & กัญ & 응 & $\frac{0}{\circ}$ & $\frac{0}{0}$ & กิ & กิ & 응 & 웅 & 웅 & 웅 & \multirow[t]{2}{*}{ 즁 } \\
\hline & & a & $\stackrel{R}{0}$ & 융 & 융 & ণ্লি & প్లి & প্ণ & 융 & প్ల & 융 & 융 & 号 & 융 & \\
\hline & \multirow{3}{*}{ 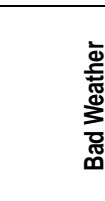 } & $\infty$ & 㣽 & 㣽 & 응 & 응 & 응 & ஜㅁㅇㅁ & ס̊: & ס̊: & $\tilde{\tilde{O}}$ & ס̊: & ஜ̊ & סु & $\mathbb{N}$ \\
\hline & & - & $\stackrel{\circ}{\circ}$ & $\stackrel{8}{\circ}$ & ণ్రి & ్ํㅇ & 令 & $\frac{0}{0}$ & 응 & 응 & $\stackrel{8}{\circ}$ & 응 & 응 & 응 & \multirow[t]{2}{*}{ 퓽 } \\
\hline & & a & ৪্ণ & প্ণি & 员 & 员 & 号 & ণ্ণি & প্লি & ஓ్ & ஓ্. & ণ্ণি & ஓ్ల & ळ్ & \\
\hline & \multirow{3}{*}{ 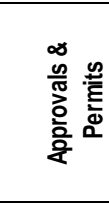 } & $\infty$ & 응 & 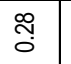 & ס̊ర్ర & 응 & ס̊: & 응 & 응 & 응 & 응 & 品 & 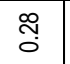 & 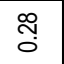 & $\frac{10}{0}$ \\
\hline & & - & న్రి & g & 응 & న్రి & 응 & กิ & న్ & กิ & న్ర & g & go & g & \multirow[t]{2}{*}{ 坖 } \\
\hline & & \begin{tabular}{|l|l|} 
a \\
\end{tabular} & 足 & R & 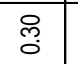 & 员 & 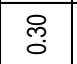 & 员 & 员 & 员 & 员 & R & 㔽 & R & \\
\hline & \multirow{3}{*}{ 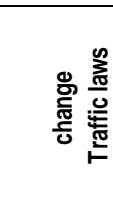 } & $\infty$ & $\stackrel{\stackrel{丶}{\Im}}{\circlearrowleft}$ & 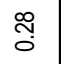 & ס̊ㅁㅇ & 응 & Oֶ. & ס̊ㅇㅁ & ס̊ㅇㅇ & ס̊: & ס̊: & ס̊: & 응 & ס̊: & $\begin{array}{l}\% \\
0 \\
\end{array}$ \\
\hline & & - & 웅 & 앙 & 응 & న్ণ & 응 & 응 & 응 & 응 & 응 & 응 & กัญ & $\frac{}{\circ}$ & \multirow[t]{2}{*}{ 冞 } \\
\hline & & \begin{tabular}{l|l} 
\\
\end{tabular} & R & R & প্ল & مُ & প్రా & প్ల & প్లి & প্ল & প్ల & প্লি & 号 & প్ల & \\
\hline & \multirow{3}{*}{ 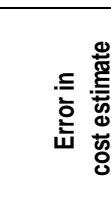 } & $\infty$ & 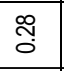 & $\stackrel{\substack{0 \\
0}}{0}$ & 응 & $\stackrel{\substack{0 \\
0}}{0}$ & 응 & 응 & 응 & 응 & ס̊: & 号 & 品 & 品 & $\begin{array}{l}0 \\
\end{array}$ \\
\hline & & - & 웅 & 웅 & ণ్రి & 웅 & ণ্ণ & ণ్రి & ণ్ণి & ণ్రి & 응 & 昌 & 导 & 昌 & \multirow[t]{2}{*}{\begin{tabular}{|l|l} 
즁 \\
\end{tabular}} \\
\hline & & a & R & R & 员 & R & . & 员 & 员 & 员 & 용 & 六 & ? & ? & \\
\hline & & 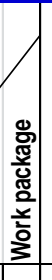 & 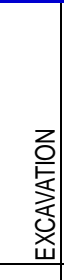 & $\begin{array}{l}\mathrm{w} \\
\vec{w} \\
\underline{0} \\
\underline{0} \\
0\end{array}$ & 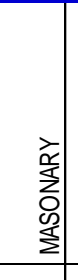 & 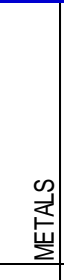 & 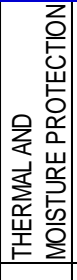 & $\begin{array}{l}\infty \\
0 \\
0 \\
3 \\
\infty \\
0 \\
0 \\
8 \\
0\end{array}$ & 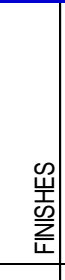 & 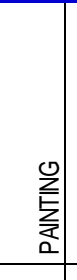 & 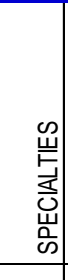 & 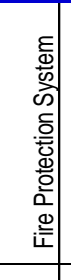 & 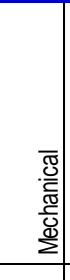 & 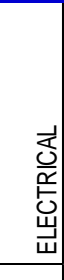 & \\
\hline & & & & & & $\sigma$ & & 6 & 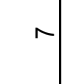 & $\infty$ & $\sigma$ & $\tau$ & $\mp$ & $\simeq$ & \\
\hline
\end{tabular}


Table 144.

Risk Treatment summary - Source: Author

\begin{tabular}{|c|c|c|}
\hline Quantitative & Risk Response & Watch list \\
\hline Damage in electrical resources & Rocks & Cut cables during work \\
\hline $\begin{array}{l}\begin{array}{l}\text { Damage in } \\
\text { equipment }\end{array} \\
\end{array}$ & Poor Design & \\
\hline Defective Delivery Material & Low Production Rate & \\
\hline $\begin{array}{ll}\text { Improper } & \text { Project } \\
\text { Management } & \end{array}$ & Error in the execution method & \\
\hline $\begin{array}{l}\text { an apology some Suppliers } \\
\text { for delivery material }\end{array}$ & Custom Tariff & \\
\hline $\begin{array}{l}\text { Transfer to unqualified sub- } \\
\text { contractor }\end{array}$ & change Traffic laws & \\
\hline Dollar exchange rate & Approvals \& Permits & \\
\hline Delay in pay invoice amount & $\begin{array}{l}\text { Lack of workers do not complete } \\
\text { the schedule }\end{array}$ & \\
\hline Error in cost estimate & Error in time estimate & \\
\hline Bad Weather & $\begin{array}{l}\text { the resignation of specialized } \\
\text { employment }\end{array}$ & \\
\hline Safety & & \\
\hline
\end{tabular}

\subsection{Risk Monitoring and control}

Risk monitoring and control for the project need to be done through dedicated team for risk analysis. They must use risk register method in order to monitor planned risk and identify new risk arise during project stages; in order to act accordingly with proper action that will improve the performance of project. 


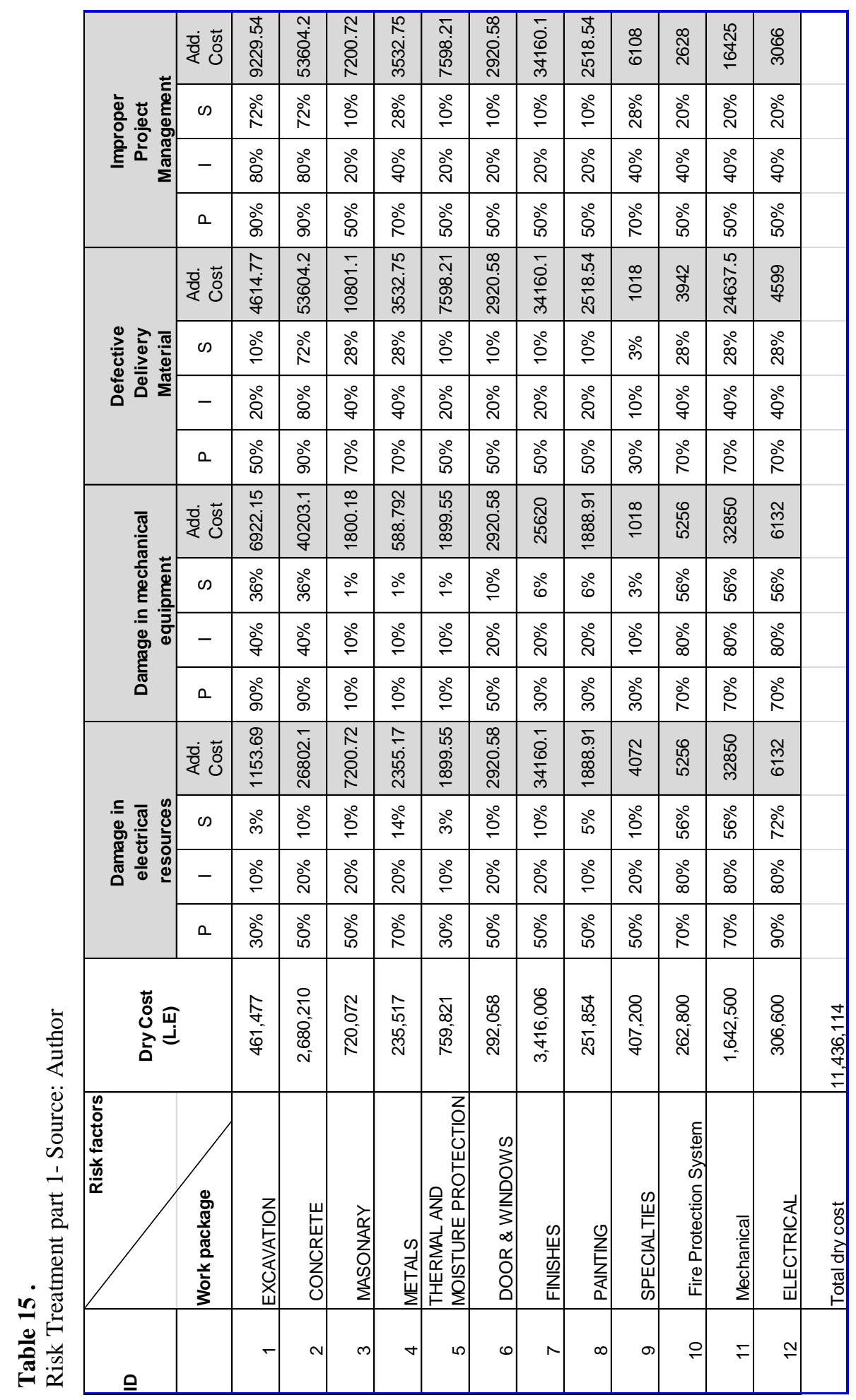




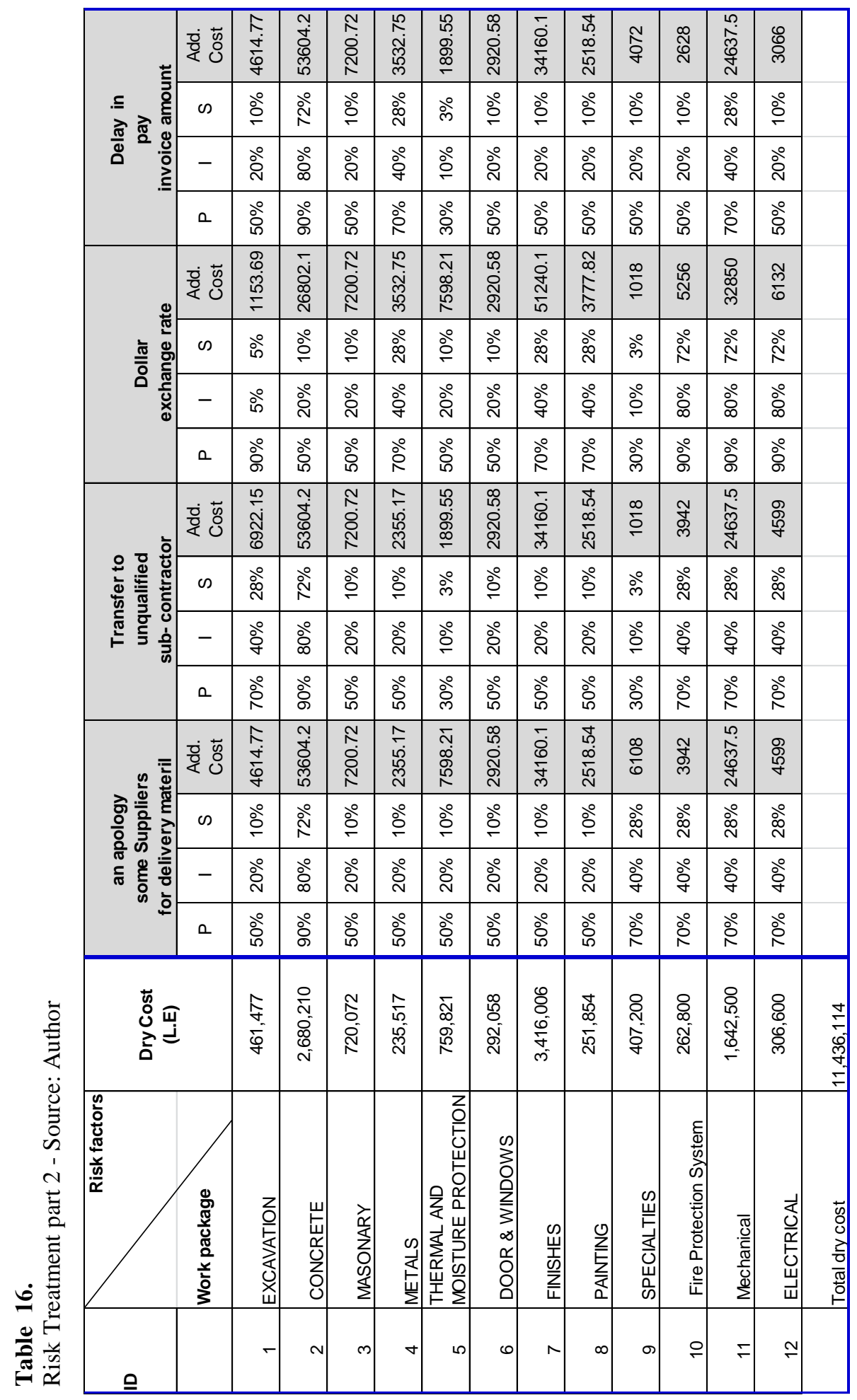




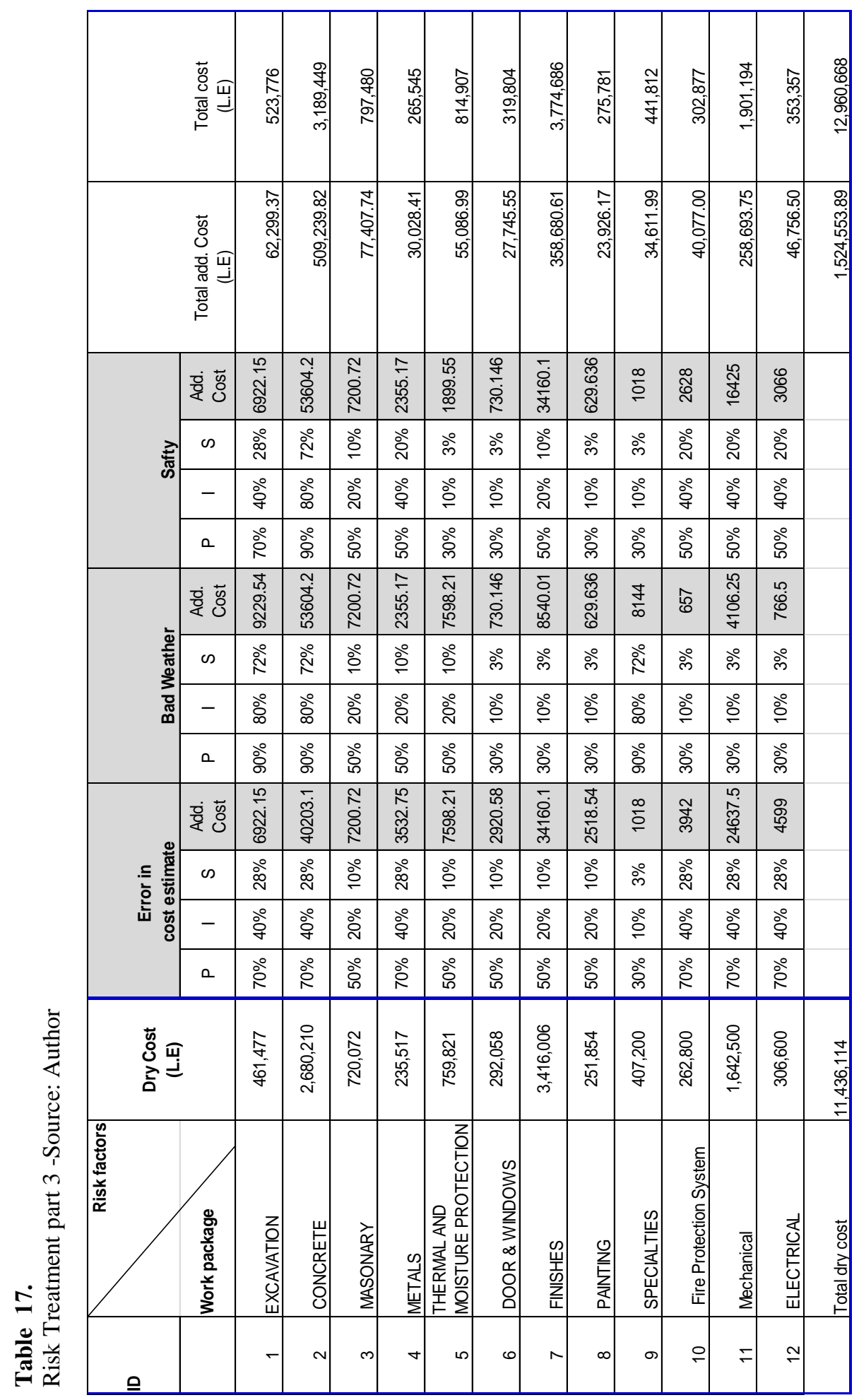




\section{Conclusion}

- Risk analysis has a large impact on improvement of project performance that need to be taken in consideration during all project stages.

- Table (18) shows the added cost for quantitative risks that will cause increase of project cost; these risks must be taken in consideration by preparing the treatment plan for different risks in order to improve the cost performance which leads to improve the public construction projects performance using risk analysis and its methodology.

Table 188.

Risk Added Cost - Source: Author

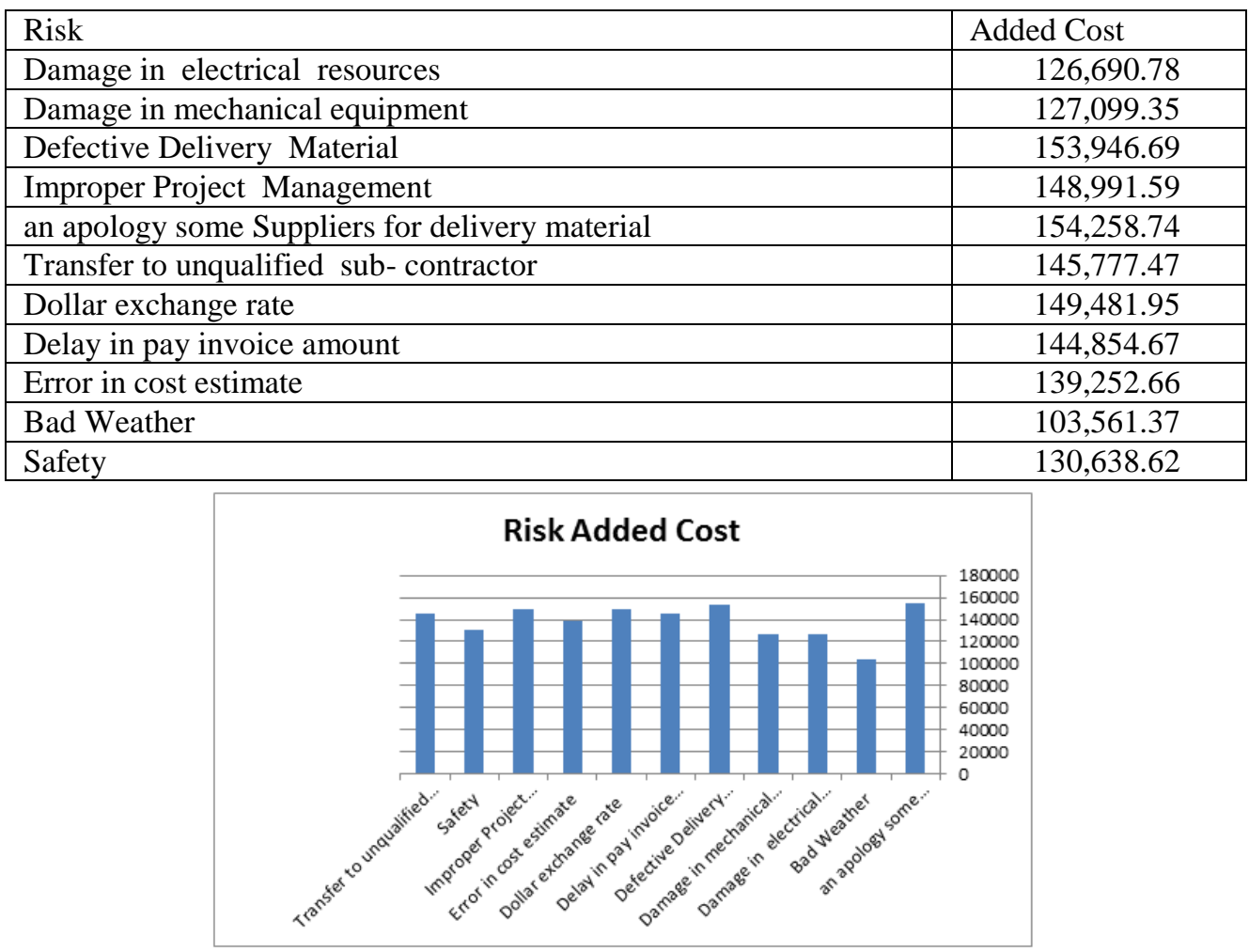

- The additional cost values are considered as an indicator of risk priority, as it has a sum of around $13 \%$ of total project cost which is considered relative high percentage that could be lowered using computerized programs for risk analysis. the additional cost in the research is considered as an indicator for risk priority that need to be taken in consideration in future projects. This risk will have an impact on project that need to be monitored and controlled to improve the projects performance.

- Table (19) shows risks that will affect the performance of project if we didn't put it in consideration, there is no need to treat risks by adding additional cost; and it could be treated during the agreements stage or contract preparation between the different parties that can achieve benefits for all the stakeholders. 
Mohamed Said Meselhy Elsaeed, Performance improvement for public construction projects ....

Table 19.

risk response - Source: Author

\begin{tabular}{|l|}
\hline \multicolumn{1}{|c|}{ Risk Response } \\
\hline Rocks \\
\hline Poor Design \\
\hline Low Production Rate \\
\hline Error in the execution method \\
\hline Custom Tariff \\
\hline change Traffic laws \\
\hline Approvals \& Permits \\
\hline Lack of workers do not complete the schedule \\
\hline Error in time estimate \\
\hline the resignation of specialized employment \\
\hline
\end{tabular}

- Construction projects are unique process that differs from one project to another, although it seems repetitive process to non-specialized. The risks mentioned in the research are not limited for all projects; other projects may have different risks. The risk analysis for each project must be taken in consideration according to risk plan shown in the research.

- In the Practical field, All the partners in the construction industry (the owner, the consultant and the contractor) must take in their consideration the risk treatment methodology and risk job plan to apply it in the life cycle of the project starting from the feasibility studies to operation and maintenance stage to achieve better performance for the projects in the three main aspects in cost, time quality.

\section{REFERENCE}

[1] Cooper D., Grey S., Raymond G., (2005). Project Risk Management guidelines, managing risk in large projects and complex procurement.

[2] JOURNAL ARTICLE Managing Project Risks Using a Cross Risk Breakdown Matrix

[3] David Hillson, Sabrina Grimaldi and Carlo Rafele, (2006). Risk Management, Vol. 8, No. 1, pp. 6176,Published by: Palgrave Macmillan Journals

[4] Kerzner, Harold.Projec. (2009).Management a systems approach to planning, scheduling, and controlling 10th edition, Published by John Wiley \& Sons, Inc., Hoboken, New Jersey Published simultaneously in Canada.

[5] A.Samer Ezeldin, The Professional program in Project Management (PRMG). (2009).Project Risk Management (PRMG095), American University in Cairo Lectures.

[6] Piney, Crispin. (2012). Integrated project risk and issue management. Paper presented at PMI® Global Congress 2012 -EMEA, Marsailles, France. Newtown Square, PA: Project Management Institute.

[7] A Guide to the Project Management Body of Knowledge (PMBOK® Guide)-Fifth Edition, Library of congress cataloging in publishing date, published by project management institute, Ins .Pennsylvania, USA, 2013.

[8] Devaux, Stephen. 1999. Total project control: A manager's guide to integrated project planning, measuring, and tracking. New York: Wiley.

[9] Thomas S. Coleman, Bob Litterman (Foreword). (2012).Quantitative Risk Management, A Practical Guide to Financial Risk.

[10] Clifford Rossi. (2014). A Risk Professional's Survival Guide: Applied Best Practices in Risk Management. 1st Edition.

[11] Randal Wilson. (2014). Mastering Risk and Procurement in Project Management: A Guide to Planning, Controlling, and Resolving Unexpected Problems. 1st Edition.

[12] Professional program in project management,(2012) American University in Cairo.

[13] Hubbard, Douglas (2009). The Failure of Risk Management: Why It's Broken and How to Fix It. John Wiley \& Sons. p. 46

[14] Antunes, Ricardo; Gonzalez, Vicente (3 March 2015). "A Production Model for Construction: A Theoretical Framework". Buildings. 5 (1): 209-228.

[15] Financial stability report of the Arabic Republic of Egypt, (2014), prepared by the central bank of Egypt, p. 16. 


\section{تحسين أداء مشروعات التشييل العامه بإستخدام تحليل المخاطر}

\section{ملخص البحث:}

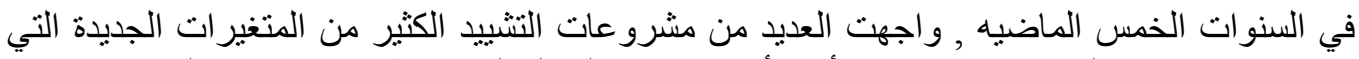

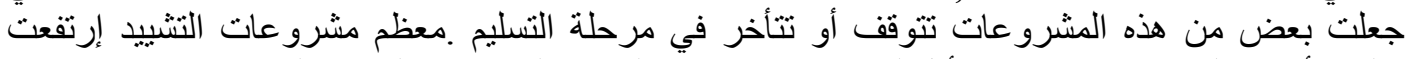

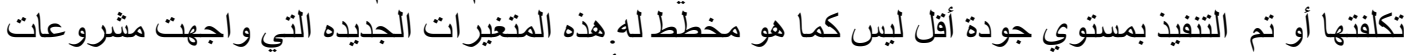

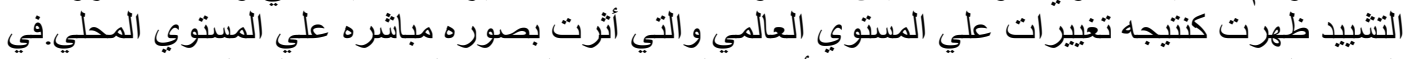

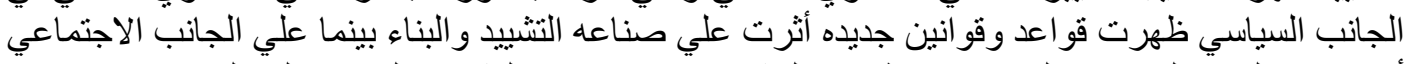

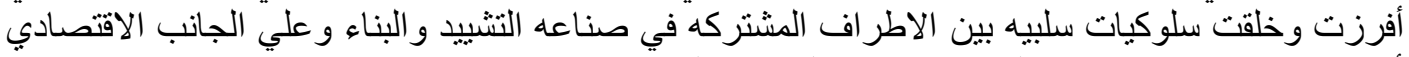

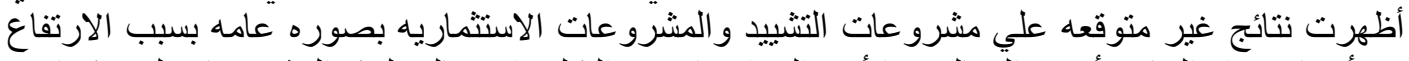

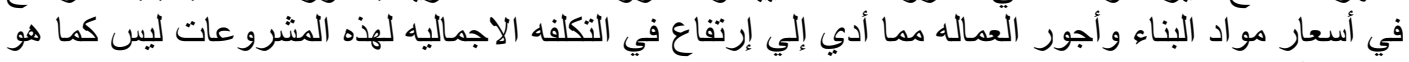
مخطط له أله

يهدف البحث إلي تحقيق خطه عمل تحليل المخاطر و الذي يؤدي إلي تحسين أداء مشروعات التشييد

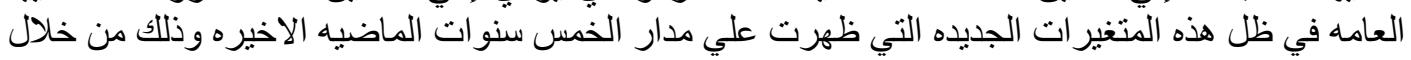

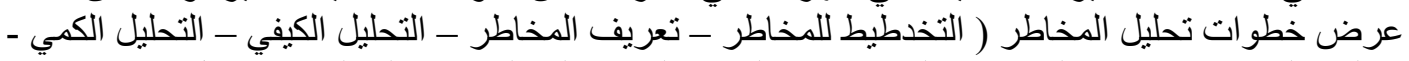

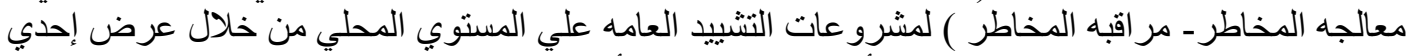

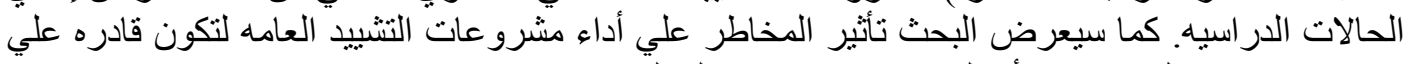
مو اجهه الاحداث الغير مؤكدة أو الغير منوقيه لإنه في مرحله التتفيذ.

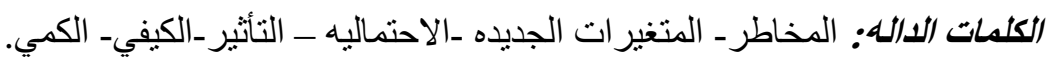

